\title{
COVID-19 PANDEMIJOS ITAKA PASAULIO EKONOMIKAI TURIZMO INDUSTRIJOS KONTEKSTE
}

\author{
Rima Karsokienè, Leta Dromantienè \\ Klaipedos universitetas
}

\begin{abstract}
Anotacija
Turizmo industrija išgyvena patị sunkiausią savo istorijos laikotarpị dèl $2020 \mathrm{~m}$. sausio $30 \mathrm{~d}$. Pasaulio sveikatos organizacijos (PSO) paskelbtos COVID-19 krizès, kuri laipsniškai virto ir $2020 \mathrm{~m}$. kovo $11 \mathrm{~d}$. įvardyta kaip pasaulinè pandemija. Kelionių suvaržymai, įvesti siekiant stabdyti viruso plitimą, pragaištingai paveike turizmo verslą visame pasaulyje. Turizmas - svarbi pasaulio ekonomikos infrastruktūros dalis, Jungtinių Tautų Pasaulio turizmo organizacijos duomenimis, generuojanti 10 proc. bendrojo vidaus produkto ir išlaikanti 1 iš 10 visų pasaulio darbo vietų. Turizmo sektorius ypač dinamiškas, kur būtina greita reakcija ị kintančią aplinką ir rinką. Be to, turizmas yra labiausiai COVID-19 pandemijos paveiktas sektorius. Būtinas išsamus šiuolaikinio turizmo tyrimas ir vidinių bei išorinių išteklių analizè. Rinkos pokyčių suvokimas yra esminis veiksnys, leidžiantis išlikti versle turizmo produktą kuriančioms įmonèms. Iššūkių kelia ir technologinė pažanga, kurią skatina tiek pačių technologijų tobulèjimas, tiek saugumo pandemijos metu aspektai. Šiame straipsnyje analizuojama COVID-19 pandemijos įtaka turizmo sektoriui pasaulyje, kuris apima kruizinių laivų ir oro linijų pramonę bei apgyvendinimo sektorių. Sėkmingai sunkumus įveikia įmonès, preventyviai stebinčios ir vertinančios esminius veiklos rodiklius: jei rodikliai netenkina, imasi visų įmanomų veiklą gerinančių priemonių. Sklandus ir savalaikis restruktūrizavimo procesas leidžia laikinų sunkumų turinčioms įmonèms performuoti savo veiklą, keičiant įmonès strategiją, atsisakant nepelningų veiklos formų ir koncentruojantis ties efektyviausiomis.

PAGRINDINIAI ŽODŽIAI: turizmo industrija, turizmo sektorius, pasaulio ekonomika, COVID-19, pandemija, poveikis.
\end{abstract}

\begin{abstract}
The Covid-19 pandemic that was announced by the World Health Organization (WHO) on 30 March 2020 has caused blockages in all economic sectors, but tourism is the most affected. It is difficult to estimate the real impact of the pandemic on international tourism. Travel restrictions imposed to stop the spread of the virus have had a devastating impact on the tourism industry around the world. According to the United Nations World Tourism Organization, tourism is a vital part of the infrastructure of the world economy, generating $10 \%$ of total gross domestic product (GDP), and accounting for one out of ten of all jobs. The tourism sector is very dynamic, requiring a rapid response to a changing environment and market; but it is also most affected by the Covid-19 pandemic. Modern tourism requires urgent research, and the analysis of internal and external resources. The perception of changes in the market is a key factor enabling companies to stay in business. Challenges are also posed by technological advances, driven by both the technological advances themselves and safety aspects during the pandemic. This article presents the effects of the Covid-19 pandemic on the tourism sector globally, which includes the cruise ship and airline industries, and also accommodation. The difficulties are successfully overcome by companies that proactively monitor and evaluate key performance indicators: if the indicators are unsatisfactory, they take all possible measures to improve performance. A smooth and timely restructuring process allows companies in temporary difficulty to reshape their operations by changing their strategy, abandoning unprofitable forms of activity, and focusing on the most efficient ones.
\end{abstract}


COVID-19 PANDEMIJOS ITTAKA PASAULIO EKONOMIKAI TURIZMO INDUSTRIJOS...

KEY WORDS: tourism industry, tourism sector, world economy, Covid-19, pandemic, impact.

DOI: http://dx.doi.org/10.15181/tbb.v86i1.2267

\section{Ivadas}

Globalizacija ir žmonių judejjimas sudarè palankias sąlygas COVID-19 virusui plisti tarpvalstybiniu mastu. Prie šios visuomenès sveikatos krizès prisidèjo žmonių kelionès, kurių suvaržymai, ịvesti siekiant stabdyti viruso plitimą, pragaištingai paveike turizmo verslą visame pasaulyje. Prasidejjus pandemijai vien Europos Sajungoje (ES) iškilo rizika netekti 13-os milijonų darbo vietų. ES parama savo narèms, būtina, siekiant po koronaviruso pandemijos atgaivinti turizmo sektorių, ịvertinta $255 \mathrm{mlrd}$. Eur. Dar maždaug $120 \mathrm{mlrd}$. Eur sudarys papildomos investicijos, kurios turètų padèti turizmu besiverčiantiems verslininkams atsigauti (ESKK, 2020).

Europos Parlamento duomenimis, vien Europos Sajungoje turizmo pramonę siauraja prasme (tradiciniai atostogų ir turizmo paslaugų organizatoriai) sudaro 2,3 mln. įmonių - daugiausia mažosios ir vidutinès, kuriose ịdarbinta maždaug 12,3 mln. žmonių. 2014 m. viena iš dešimties Europos nefinansinès ekonomikos imoniu priklause turizmo sektoriui. $2018 \mathrm{~m}$. ES kelionių ir turizmo sektorius tiesiogiai sukūrè 3,9 proc. BVP ir 5,1 proc. darbo vietų, t. y. įdarbino apie 11,9 mln. žmonių I Ivertinus glaudžius turizmo sektoriaus ryšius su kitais ekonomikos sektoriais, manoma, kad jo indèlis yra dar didesnis - 10,3 proc. BVP ir 11,7 proc. visų darbo vietų, t. y. ịdarbinta 27,3 mln. žmonių (EP, 2021).

2019 m. pasaulyje tarptautinių turistų skaičius siekẻ 1,5 mlrd., Europoje 745 mln., t. y. sudare 50 proc. rinkos (EP, 2021). 2020 m. kovą ịvykęs COVID-19 pandemijos protrūkis, dẻl kurio kilo nemažai diskusijų, susijusių su draudimais keliauti ir higienos prievolèmis, šiandien yra didžiausias iššūkis turizmo industrijos sektoriuje.

Problema. COVID-19 pandemijos įtaka pasaulinio turizmo, kaip vienos svarbiausių ekonomikos sričių, nuosmukiui.

Tikslas: išanalizuoti COVID-19 poveikị turizmo industrijai.

Objektas: COVID-19 poveikis turizmo industrijai pasaulio mastu.

Uždaviniai:

- Apžvelgti COVID-19 pandemijos poveikị didžiausių pasaulio ekonomikų septynetui.

- Atskleisti COVID-19 pandemijos padarinius skirtingiems turizmo sektoriams.

- Pateikti turizmo industrijos sektoriaus restruktūrizacijos principus. 
Metodika. Taikyta santykinai nestruktūruota dokumentų analizè. Anot A. Čiužo (2021), ji pagrịsta tyrèjo gebèjimu įsigilinti į dokumentų turinį, sprendžiant straipsnyje pateiktus uždavinius bei pagrindžiant išvadas. Atskleidžiamos pagrindinès mintys ir idèjos, dèsningumai, loginiai ryšiai bei tendencijos. Tiriamas reiškinio, šiuo atveju COVID-19 pandemijos, poveikis turizmo industrijai. Pasirinkta išnagrinèti mokslinę, teisinę literatūrą, finansinių kelionių organizatoriu ataskaitas ir atlikti statistikos duomenų analizę. Tai naudinga tyrinejjant santykinai nedideli uždavinių skaičių siaurame tyrimo lauke. Remtasi užsienio šalių ir Lietuvos moksline literatūra, daugiausia 2016-2021m., parinkta per Klaipėdos universiteto bibliotekos elektroninius išteklius: Scholar Google bei virtualiosios bibliotekos duomenų platformas, SFX, DOI sistemas, EBSCO mokslinių duomenų bazę. Naudotos ir Europos Sajungos duomenų bazès, tokios kaip eur-lex.europa bei ec.europa. Analizuoti statistiniai duomenys, gauti iš Worldometer, SATISTA, Stat.gov, VVTAT, Eimin.lrv duomenų portalų.

\section{Pandemijos padarinių vertinimas, remiantis didžiausių pasaulio ekonomikų septyneto rodikliais}

Globali socialinė ir ekonominė struktūra dar nebuvo patyrusi tokio staigaus ir daugialypio sukrètimo, kaip COVID-19 pandemija. Ženevos ekonomikos instituto ir Londono Ekonomikos vadybos tyrimu centro (angl. Center for Economic Policy Research-CEPR), kuriam priklauso daugiau kaip 1500 tyrèjų ekonomistų, išleistoje knygoje "Economics in time of COVID-19" mokslininkai ekonomistai R. Baldwin'as ir B. W. Di Mauro (2020) COVID-19 pandemiją ịvardijo kaip ekonomikos pandemiją. Jų teigimu, virusas tiek žmonių sveikatą, tiek ekonomines struktūras veikia tokiu pačiu pagreičiu. Didžiajam pasaulio ekonomikų septynetui priklausančios šalys, tokios kaip JAV, Kinija, Japonija, Vokietija, Jungtinè Karalystè, Prancūzija ir Italija, generuoja:

- $60 \%$ pasaulio bendrojo vidaus produkto;

- $65 \%$ visos pasaulio gamybos;

- $41 \%$ viso pasaulio gamybos eksporto. 
COVID-19 PANDEMIJOS ITTAKA PASAULIO EKONOMIKAI TURIZMO INDUSTRIJOS...

Pasaulio statistikos duomenų bazès "Statista" $2021 \mathrm{~m}$. vasario 22 d. duomenimis, dauguma šių šalių ir sudare labiausiai COVID-19 paveiktų šalių pasaulio dešimtuką (žr. 1 lentelę).

1 lentele. Šalių, labiausiai paveiktų COVID-19, dešimtukas

\begin{tabular}{|c|c|c|c|c|c|}
\hline \multirow[t]{2}{*}{$\begin{array}{l}\text { Šalies } \\
\text { pavadinimas }\end{array}$} & \multirow[t]{2}{*}{$\begin{array}{l}\text { COVID-19 } \\
\text { atvejų sk., } \\
\text { vnt. }\end{array}$} & \multirow[t]{2}{*}{$\begin{array}{l}\text { Mirčių } \\
\text { sk., vnt. }\end{array}$} & \multicolumn{2}{|c|}{$\begin{array}{l}\text { Bendrasis vidaus } \\
\text { produktas (trilijonais } \\
\text { JAV doleriu) }\end{array}$} & \multirow{2}{*}{$\begin{array}{l}\text { Pasaulio eko- } \\
\text { nomikos septyne- } \\
\text { tui priklausanti } \\
\text { šalis }\end{array}$} \\
\hline & & & $2019 \mathrm{~m}$. & $2020 \mathrm{~m}$. & \\
\hline JAV & $28,134,803$ & 498,901 & 21,43 & 19,48 & + \\
\hline Indija & $11,005,850$ & 156,385 & & & \\
\hline Brazilija & $10,168,174$ & 246,504 & & & \\
\hline Rusija & $4,130,447$ & 82,255 & & & \\
\hline D. Britanija & $4,127,574$ & 120,810 & 2,829 & 2,63 & + \\
\hline Prancūzija & $3,597,540$ & 83,546 & 2,716 & 2,58 & + \\
\hline Ispanija & $3,133,122$ & 67,101 & & & \\
\hline Italija & $2,809,246$ & 95,718 & 2.004 & 1,94 & + \\
\hline Turkija & $2,638,422$ & 28,060 & & & \\
\hline Vokietija & $2,396,496$ & 67,955 & 3,693 & 3,69 & + \\
\hline
\end{tabular}

Šaltinis: sudaryta autorių, remiantis "Statista" 2021-02-22 duomenimis.

COVID-19 viruso sukelta pandemija verte pasaulio valstybes imtis precedento neturinčių priemonių jo plitimui stabdyti. Suprasdamos, su kokiais iššūkiais susiduria pasaulio ekonomikos, valstybès rengè ekonominių ir finansinių priemonių planus, kurie pirmiausia apima gyventojų sveikatos saugumo užtikrinimą, pagalbą smulkiajam ir vidutiniam verslui, darbuotojų užimtumo ir ekonomikos skatinimą. Anot S. Barua (2020), globalios ekonomikos augimo perspektyvos trapios, kadangi COVID-19 viruso plètra pasaulyje dar nesuvaldyta. Jo teigimu, egzistuoja rizika, kad išorès aplinkos veiksnių ịtaka ekonomikai gali būti blogesnè nei prognozuota pandemijos pradžioje, o bendras pasaulio BVP $2021 \mathrm{~m}$. pasieks priešpandemini lygị tiktai ịpusèjus 2021 metams.

PSO 2021 m. kovo 15 d. duomenimis, sergančiujų skaičius pasaulyje viršijo 120 mln., o mirčių skaičius siekẻ 2,6 mln. Pasaulyje neliko šalies, kurios nebūtų paveikęs COVID-19 virusas. İmonėms kilo bankroto pavojus ir grèsmè prarasti klientus bei rinkas, žmonėms - darbo ir pragyvenimo šaltinius. Pasaulio duomenu bazès lyderio "Kantar" duomenimis, $69 \%$ pasaulio verslo lyderių planuoja 2020 m. ir $2021 \mathrm{~m}$. baigti prasčiau: beveik pusė jų teigia, kad rezultatai bus apie $20 \%$ blogesni nei ankstesniais metais, o kas penktas prognozuoja, kad rodikliai smuks $40 \%$ (2020). Tyrimo išvadose teigiama, kad daugiau nei pusè pasaulio verslo lyderių nesitiki ekonomikos atsigavimo iki $2022 \mathrm{~m}$. Tik ketvirtadalis 
verslų tiki, kad, sẻkmingai pabaigus klinikinius vakcinos bandymus ir pristačius ją rinkai, atsigauti pakaks pusmečio. $41 \%$ planuoja, kad tam prireiks mažiausiai metų, o daugiau nei kas ketvirtas teigia, jog reikès iki dvejų metų atsigauti nuo COVID-19 pandemijos. "Kantar" apklausė 4475 pasaulio verslo lyderius, tarp kurių - per 900 aukščiausio lygio vadovų, beveik 1300 direktorių, daugiau kaip 60-yje šalių. Didžioji dalis respondentų - mažmeninès prekybos, rinkodaros, konsultacijų ir finansų sektorių atstovai. Reziumuojant tyrimą, galima skirti tris veiksmingas strategijas, padėsiančias įmonėms atsigauti ir augti šiuo kritiniu laikotarpiu. Tai - skaitmeninè transformacija, prasmingas ir tvarus verslas, organizacijos struktūros našumas ir inovacijos (Kantar, 2020).

\section{COVID-19 poveikio skirtingiems turizmo sektoriams tyrimų analizė}

COVID-19 pandemija paralyžiavo beveik visus ekonomikos sektorius, tačiau labiausiai nukentejo turizmo industrija (Fernandes, 2020). Dẻl ịvesto karantino, sustabdytų skrydžių, ribojamo patekimo per valstybės sienas ir uždarytų apgyvendinimo įstaigu sumažèjo turizmo industrijos paslaugų paklausa, kartu ir pardavimai. Tad pasikeitè visas turizmo sektorius, jo veikla ir turistų skaičiai, kurie 2019 metais buvo labai dideli. Jungtinių Tautų Pasaulio turizmo organizacijos (angl. UNWTO) duomenimis, $2019 \mathrm{~m}$. visame pasaulyje keliavo apie 1,5 milijardo turistų (UNWTO, 2019). Turizmas generavo10 proc. pasaulio BVP (žr. 1 pav.), kas sudare 2,9 mlrd. JAV dolerių. Tais pačiais metais, lyginant su 2018-aisiais, turizmas išaugo 4 proc. ir prognozuota, kad panašaus augimo galima tikètis ir toliau.

Prasidëjus COVID-19 pandemijai, tarptautinių kelionių skaičius per pirmuosius dešimt $2020 \mathrm{~m}$. mėnesių smuko daugiau nei 70 proc. - iki $1990 \mathrm{~m}$. lygio (UNWTO, 2020). Kaip pavaizduota 2 paveiksle, ryškiausias kelionių mažèjimas

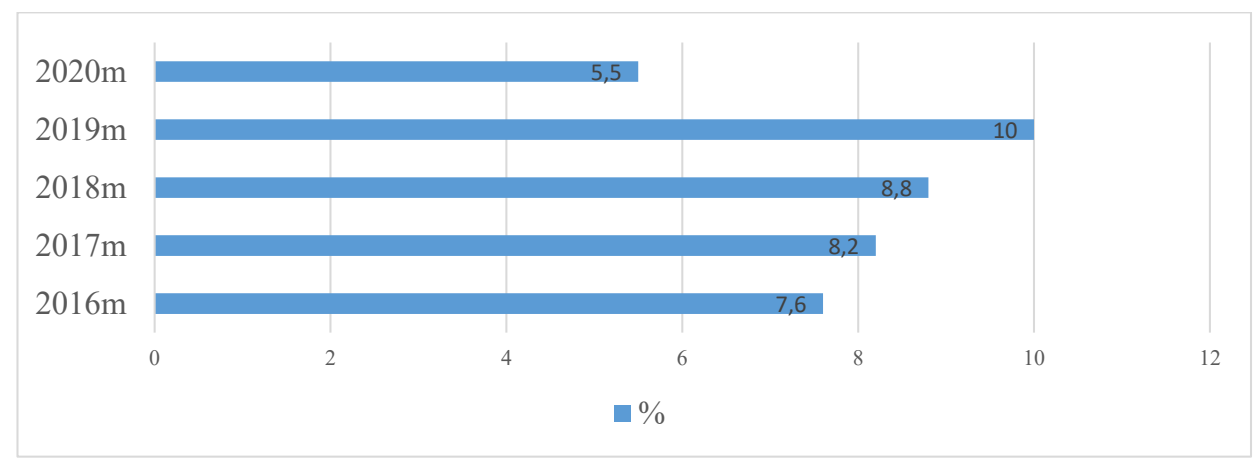

1 pav. Turizmo generuojamas BVP pasaulyje

Šaltinis: sudaryta autorių, remiantis "Statista" duomenimis. 


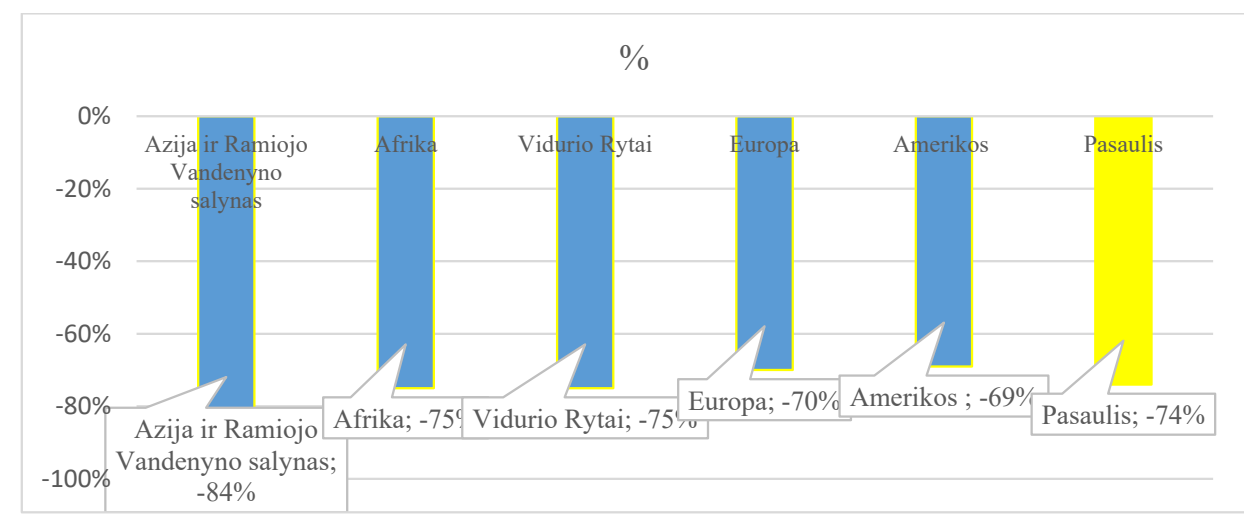

2 pav. COVID-19 įtaka turizmo industrijai pagal pasaulio regionus Šaltinis: sudaryta autorių, remiantis JTPTO duomenimis (2020).

fiksuojamas Azijos ir Ramiojo Vandenyno regione - per 10 mènesių jų skaičius sumažèjo 82 proc. Viduriniuose Rytuose sumažèjimas sudarè 75 proc., Afrikoje 69 proc., tarptautinių atvykimų į Europą ir Ameriką skaičius sumažèjo 70 proc. Ten nuosmukis buvo mažesnis trumpalaikio turizmo atsigavimo vasaros mènesiais dèka.

Organizacijos pranešime (UNWTO, 2021) teigiama, kad 2020 metai buvo blogiausi turizmo istorijoje ir tai lèmè keliavimo ribojimas, vartotojų baimės bei visame pasaulyje dedamos pastangos sustabdyti COVID-19 viruso plitimą. Buvusios populiarios kelionių vietos (angl. destinations) sulaukè milijardo mažiau turistų nei praejusiais $2019 \mathrm{~m}$. Bendrai viso pasaulio valstybès neteko 1,3 trilijono JAV dolerių pajamų, kas sudaro 11 kartų didesnius nuostolius nei pasaulinės ekonominès krizès metu 2009 metais. Beveik 120 milijonų darbo vietų, tiesiogiai susijusių su turizmo paslaugomis, patyre išlikimo riziką. Remiantis šia statistika, JTPTO teigimu, keliautojų skaičius nukrito į prieš trisdešimt metų buvusị lygị (UNWTO, 2020).

Kruizinių laivų sektorius buvo sparčiausiai pasaulyje auganti turizmo industrijos dalis. Kaip matyti 3 paveiksle, nuo 2019 m. sausio iki $2020 \mathrm{~m}$. balandžio bendras kruizinių laivų keleivių skaičius sudarè daugiau kaip $27 \mathrm{mln}$., tuo tarpu 2010 m. keleivių skaičius buvo 50 proc. mažesnis.

Sustabdytos kruizinès kelionès, dèl pandemijos protrūkių laivuose keleiviams praradus pasitikèjimą šia industrija (Menegaki, 2020). Didžiausioms trims pasaulio kruizu bendrovėms, tokioms kaip "Carnival", "Royal Carribean" ir "Norwegian", teko atleisti 800 darbuotojų, kitiems - mažinti algas. Iš viso šių trijų įmonių nuostoliai siekia $110 \mathrm{mln}$. JAV dolerių. Nebevykdant kruizų verslo, senesni britų, amerikiečių, italų kruiziniai laivai dabar ardomi Turkijos uoste, o žymiausi ir di- 


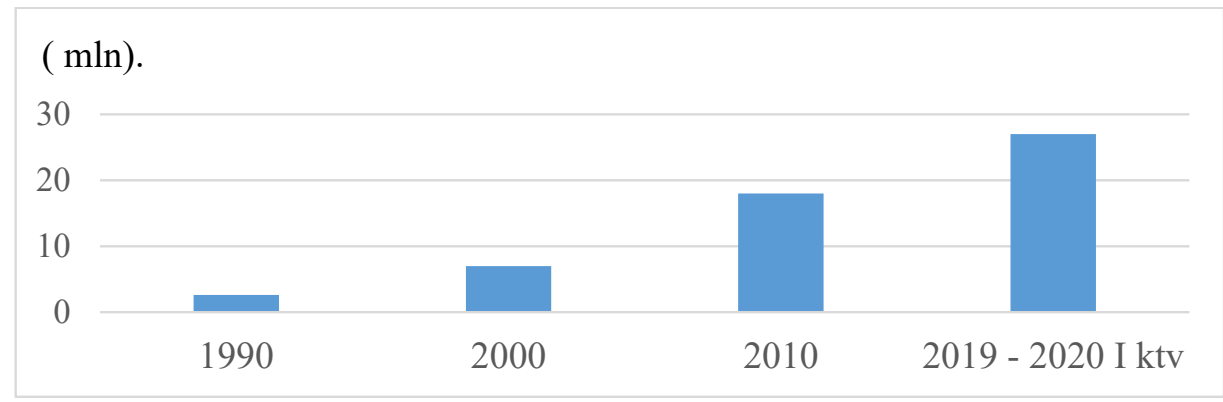

3 pav. Kruizinių laivų keleivių skaičius

Šaltinis: sudaryta autorių, remiantis "Statista" duomenimis.

džiausi kruiziniai laivai, tokie kaip "Queen Victoria”, “Queen Elizabeth", "Queen Mary 2" ir kt. plūduriuoja Lamanšo sąsiauryje, netoli Weymouth miesto Jungtinejje Karalystëje (Business insider, 2021).

Pandemijos padarinių teko patirti ir aviacijos sektoriui (Strickland, 2020). Atšaukti skrydžiai, nutupdyti lèktuvai, atostogų išleisti darbuotojai - šias priemones taikè bene visos oro linijos. Netikètai užklupus krizei, beveik visos bendrovès jaute išteklių stygių, visų pirma klientų aptarnavimo skyriuose, tad užtikrinti sklandaus šių procesų vyksmo negalëjo joks vežejjas (Costaguta, 2020). A. Costaguta'os teigimu, vien Europoje aviacijos sektorius patyrè daugiau kaip $56 \mathrm{mlrd}$. Eur siekiančius nuostolius, pasaulio mastu nuostoliai siekia $314 \mathrm{mlrd}$. JAV dolerių (2 lentelè), nuskristų kilometrų skaičius sumažèjo 48 proc.

2 lentele. Aviacijos nuostoliai pagal žemynus

\begin{tabular}{|l|l|l|}
\hline $\begin{array}{l}\text { Žemyno regionas, kur regis- } \\
\text { truota oro linijų bendrovė }\end{array}$ & $\begin{array}{l}\text { Pajamos pagal } \\
\text { nuskristus kilome- } \\
\text { trus (2020 metus } \\
\text { palyginus su 2019) }\end{array}$ & $\begin{array}{l}\text { Pajamos pagal keliautojų } \\
\text { sk., mlrd. JAV dolerių } \\
\mathbf{( 2 0 2 0} \text { metus palyginus su } \\
\mathbf{2 0 1 9 )}\end{array}$ \\
\hline $\begin{array}{l}\text { Azija ir Ramiojo vandenyno } \\
\text { salos }\end{array}$ & $-50 \%$ & -113 \\
\hline Šiaurès Amerika & $-36 \%$ & -64 \\
\hline Europa & $-55 \%$ & -89 \\
\hline Viduriniai Rytai & $-51 \%$ & -24 \\
\hline Europa & $-51 \%$ & -6 \\
\hline Lotynų Amerika & $-49 \%$ & -18 \\
\hline Bendra aviacijos industrija & $-48 \%$ & -314 \\
\hline
\end{tabular}

Šaltinis: sudaryta autorių, remiantis "IATA Economics" 2021-02-10 duomenimis. 
Skrydžių industrija išgyveno rekordinį nuosmukį, oro linijų bendrovėms teko ieškoti būdų, kaip išlikti rinkoje. Vis dèlto pandemijos iššūkiai atnešè ne tik praradimų, bet ir suteikè galimybių pasitikrinti savo stipriąsias puses, paskatino spręsti globalias problemas (Fernandes, 2020). N. Fernandes'o teigimu, $2020 \mathrm{~m}$. aviacijos sektoriuje veikiančioms įmonėms, taip pat ir oro navigacijos paslaugu teikejjams, teko iššūkis užtikrinti teikiamų paslaugų tęstinumą, kad tokie kovai su COVID-19 svarbūs kroviniai, pirmo būtinumo prekès ar su svarbiais darbo reikalais keliaujantys žmonès galètų laiku pasiekti kelionès tikslą. Europos civilinès ir karinès aviacijos organizacija "Eurocontrol" atliko COVID-19 viruso įtakos Europos oro erdvei tyrimą ir nustatè, kad skrydžių srautui Europoje grįžus ị 1980-ujjų vidurio lygi, $\mathrm{CO}_{2}$ emisija sumažèjo daugiau nei per pusę: ilgai siekti tikslai, susiję su šiltnamio efektą sukeliančių dujų emisijos kiekio mažinimu, lengvai pasiekti (Eurocontol, 2021). Aviacijos specialistai greito sektoriaus atsigavimo neprognozuoja. Nors vakcinacija nuo COVID-19 jau prasidejo, ribojimas keliauti dèl viruso plitimo rizikos kurị laiką dar gali išlikti, tai neleis aviacijos sektoriui greitu metu pasiekti 2019 m. skrydžių srautų lygio. Remiantis "Eurocontrol" pateiktomis skrydžių srautų prognozėmis, atsižvelgiant ị vakcinacijos pradžią ir vakcinų veiksmingumą, 2019 m. skrydžių srautų lygị Europos aviacijos sektorius galimai pasieks tik 2024-2026 m. Prognozuojama, kad $2021 \mathrm{~m}$. Europoje bus atlikta tik 51 proc. skrydžių, palyginus su $2019 \mathrm{~m}$. Dẻl užsitęsusių kelionių ribojimo tikètina, kad gali gerokai išaugti oro linijų bendrovių bankroto rizika, tad visame pasaulyje ieškoma sprendimų dèl galimos finansinès pagalbos aviacijos sektoriaus ịmonèms (Eurocontrol, 2021).

Remiantis M. Benbouziane'u, T. Saidi (2020), ir apgyvendinimo sektorius visame pasaulyje išgyveno COVID-19 viruso sukeltą pandemijos efektą. Amerikos viešbučių ir apgyvendinimo asociacijos (angl. American Hotel and Lodging Association - AHLA) 2020 m. lapkričio 10-13 d. atliktos apklausos, kai apklausta 1200 asociacijos narių, duomenimis, 71 proc. viešbučių, valstybei neįsikišus, t. y. nesuteikus finansinès pagalbos ar atšaukus karantino ribojimų, bankrutuos per ateinančius 6 mènesius. Be to, skelbta, kad 77 proc. iki $2021 \mathrm{~m}$. vasaros sezono turès atleisti dalị darbuotojų (AHLA, 2020).

Remiantis 2020 m. "Statista" duomenimis, viešbučių užimtumas pasaulio mastu, prasidejus COVID-19 pandemijai, smuko 32 proc., tuo tarpu maitinimo sektoriaus pajamos tais metais buvo 90 proc. mažesnès nei 2019 m. Viešbučiu užimtumo rodikliai pasaulyje pradejjo mažèti dar 2019 m. pabaigoje, pasirodžius pirmiesiems duomenims apie plintantị COVID-19 virusą. Iki $2021 \mathrm{~m}$. kovo viešbučių užimtumo rodikliai visame pasaulyje krito 30 proc.

Europoje šaliu patirtis skirtinga: vienur viešbučiai naudojami sugrį̌usių šalies piliečių karantinui, kitur - medicininėms reikmėms. Kaip minima T. Baum'o ir 
N. T. T. Hai (2020) COVID-19 poveikio apgyvendinimo sektoriui analizeje, Ispanijos viešbučių savininkų asociacija pati kreipèsi ị Vyriausybę su prašymu stabdyti viešbučiu darbą, siekiant mažinti infekcijos plitimą ir sektoriaus praradimo riziką. Madride 40 viešbučiu pasiūlè daugiau kaip 10000 vietų skubiosios pagalbos reikmėms. Viešbučiai uždaryti ir Kipre, išskyrus tuos, kurie susitarè su Vyriausybe dèl patalpų karantino reikmėms teikimo. Už dvivietị kambarị valstybė moka 90 Eur, už vienvieti - 60 Eur (Baum, Hai, 2020).

Atlikta nemažai kitų viešbučių sektoriaus analizių ịvairiais lygmenimis - tiek regioniniu, tiek globaliu. D. Dinarto, A. Wanto, L. C. Sebastian'as (2020) tyrinejjo COVID-19 ịtaką apgyvendinimo sektoriui Bintano saloje, Indonezijos Riau archipelago salyne; R. S. Centeno, J. P. Marques'as (2020) nagrinejo apgyvendinimo sektoriaus nuostolius Filipinuose; Europoje L. C. Correa-Martines'as ir kt. (2020) išanalizavo COVID-19 pandemijos įtaką Austrijos slidinejjimo kurortams. S. K. Nepal'as (2020) savo moksliniame straipsnyje analizavo pandemijos padarinius Nepalo apgyvendinimo sektoriui. Yra nemažai mokslinių darbų, nagrinejjančiu viruso įtaką apgyvendinimo sektoriui globaliu mastu. S. Gossling'as, D. Scott'as ir C. M. Hall'as (2020) įvertino tarptautinių karantino suvaržymų padarinius viešbučiu industrijai, be to, tyrè izoliavimosi dèl karantino poveikị žmogaus psichologijai. N. G. Ugur'as ir A. Akbiyik (2020) atliko portalo "Trip Advisor" duomenų analizę, kurios metu išaiškèjo keliautojų baimès ir masiškai atšaukiamų viešbučiu rezervacijų priežastys. Pasaulio turizmo ir svetingumo industrijai COVID-19 pandemija sukèlè ne tik ekonominių, bet ir socialinių padarinių.

Akivaizdi turizmo industrijos krizé pasaulio mastu sulaukia pelnyto mokslininkų dėmesio, nors ji nèra pirmoji. „Pasaulyje vykstantys karai, teroristų išpuoliai, klimato atšilimas ir kitos stichinès nelaimès sąlygoja turizmo krizių atsiradimą visame pasaulyje“ (Jucaitytè, Maščinskienè, 2012, p. 1076). Turizmas jau išgyveno tokias krizes, kaip JAV $2001 \mathrm{~m}$. rugsėjo 11-osios, kitas teroristines atakas, Didžiają finansinę krizę $2008 \mathrm{~m}$. ir Didžiają depresiją XIX a. pradžioje. Z. Maditinos (2008) skiria keturias krizių priežastis: terorizmas, stichinès nelaimès, politiniai neramumai arba karai ir pandemijos. N. A. Bakar'io ir S. Rosbi'o (2020) teigimu, šios pandemijos padariniai turizmui turès didesnị žlugdanti poveikị nei kokia kita kada nors nutikusi finansinè krizè. Bet kokia krizè skatina imtis veiksmų turizmo plètotei vietovėse, kurias ištiko krizè, tačiau COVID-19 metu susidariusiai situacijai ịvertinti, suvaldyti ir atrasti sprendimų, kaip ją gerinti ar iš dalies regeneruoti, viso pasaulio mokslininkai, gydytojai, įvairių ekonomikos sričių ekspertai ir kiti specialistai telkia jègas atlikdami tyrimus ir skelbdami rezultatus savo moksliniuose darbuose.

Taigi galima teigti, kad turizmo industrijos įmonių ir organizacijų savininkams, vadovams bei darbuotojams svarbu laikytis daugialypio plano, imantis išlaidụ 
kontrolės, pagrindinių darbuotojų išlaikymo, ryšių su klientais išsaugojimo rinkodaros strategijos. Visa apimanti kelionių industrija, kartu su civiline aviacija, pradedant internetinèmis platformomis, dinamine kainodara, lojalumo programomis ir baigiant patirčiu pirkimu bei virtualia realybe, yra labiausiai pažengusi inovacijų srityje. Turizmo industrijos problema tapo ne verslo modeliai, o jų igyvendinimo galimybès - sienų uždarymas ir pasaulinè skolų grandinė pirmają pandemijos savaitę. Turizmo sektorius nepasirengęs savarankiškai ịveikti tokio masto krizių nè vienoje pasaulio šalyje (Baum, Hai, 2020). Tam reikia visapusiškos valstybių finansinès pagalbos ir susitarimų, tokių kaip skiepijimas COVID-19 vakcina, skaitmeninio pažymėjimo įvedimas, naujų technologijų diegimas, susitelkimas ties darbuotojų gebejjimu prisitaikyti prie besikeičiančių verslo sąlygų, įmonių valdymo strategijų kaita, įmonių vadybos modelių reorganizavimas.

\section{Turizmo industrijos sektoriaus restruktūrizavimo tyrimų apžvalga}

Pasak B. Chris'o, M. Hirt'o, S. Hudson'o, N. Northcote ir S. Smit'o (2020), prasidèjus pandemijai, kelerius metus kelionių organizavimo rinkoje turèjęs trukti skaitmenizacijos procesas užtruko vos keletą mėnesių. Imonès privalèjo restruktūrizuoti savo veiklą, diegdamos naujausias skaitmenines technologijas, pereidamos prie naujų internetinių užsakymų platformų, nes, autorių teigimu, naujosioms technologijoms rinkoje ịgaunant vis didesnę svarbą, tradicinių kelionių organizatorių ir agentūrų mažès, išliks tik geriausiai prisitaikę prie pakitusių verslo sąlygų.

Dar prieš pandemiją, R. Law, R. Leung'as ir D. Buhalis (2009) savo moksliniame straipsnyje pateikè informacinių technologijų (IT) svarbos, siekiant užtikrinti sėkmingą kelionių agentūrų veiklą, tyrimo rezultatus. Pasirinktas turinio analizès metodas, kurị taikant išanalizuota 215 straipsnių, susijusių su IT turizmo ir kelionių agentūrų versle. Duomenys suskirstyti ị tris kategorijas: technologijų pletros svarba kelionių organizavimo versle, kelionių organizavimo paslaugų teikejjai ir jų vartotojai. Atlikę tyrimą autoriai padarè išvadą, kad IT kelionių agentūrų versle tampa vis svarbesnès, nes leidžia mažinti darbo sąnaudas, didinti darbo efektyvumą ir gerinti teikiamų paslaugų kokybę.

Grį̌̌kime prie popandeminio laikotarpio, ị 2021 metus. Kelionių organizavimo ir jų sklaidos sistemos industrijoje Ispanijoje restruktūrizacijos problemą nagrinèjo ir T. Gonzalez-Torres'as, J. L. Rodriguez-Sanches'as ir E. Pelechano-Barahona (2021). Kokybinio interviu metodu atliktame tyrime apklausti 9 respondentai, išnagrinètos pasirinktų ịmonių finansinès ataskaitos ir dokumentai. Padaryta išvada dèl įvairių darbo restruktūrizavimo procesų, tokių kaip maksimalus valstybės paramos panaudojimas, finansinès ir fiskalinès veiklos koordinavimas, kooperacija su kitais kelionių organizatoriais, patrauklumo valdymas ir kt. 
Kelionių organizavimo verslo po COVID-19 pandemijos išlikimo galimybių ir verslo organizatorių bei jų paslaugų vartotojų santykių peripetijas Ghanos pavyzdžiu nagrinejjo Vokietijos mokslininkai - A. Thams'as, N. Zech, D. Rempel'is ir A. Ayia-Koi (2020). Darbe pabrezžiama savalaikè prisitaikymo prie naujų darbo sąlygų svarba. Prieita prie išvados, kad priimti skubios restruktūrizacijos sprendimai pamažu turès būti keičiami ị ilgalaikès kelionių veiklos procesų strategijos planavimą.

Analizuojant atliktus tyrimus pastebèta tendencija, kad iki COVID-19 pandemijos daugiausia tirta naujų technologijų svarba ir jų adaptacijos kelionių organizavimo versle galimybès. Popandeminiu laikotarpiu labiau susitelkta ties darbuotojų gebëjimu adaptuotis prie besikeičiančių verslo sąlygų, įmonių valdymo strategijų kaitos galimybėmis, pereita prie įmonių vadybos modelių bei vartotojų kelionių ipročių kaitos analizès. Atlikta straipsnių analizè leidžia teigti, kad prasidejjus pandemijai ịvyko ryškūs pokyčiai turizmo industrijos versle, nors poveikis turizmo industrijos struktūroms yra panašus, jų veiklos organizavimo aspektai priklausė nuo ịmonių gebèjimo prisitaikyti prie naujos verslo aplinkos.

\section{Diskusija}

Turizmo sektorius ịvardijamas kaip labiausiai COVID-19 pandemijos paveikta ekonomikos sritis, kurią būtina priverstinai restruktūrizuoti. Restruktūrizacijos procesai suteikia didžiausią augimo potencialą, tad šio sektoriaus plètra sulaukia pelnyto ịvairių tyrinètojų dėmesio. Analizuojant atliktus turizmo verslo transformacijos tyrimus pastebèta tendencija, kad didžiausi pokyčiai siejami su informacinių technologijų ir interneto plètra. Pandemija, be abejo, paskatino „bekontakčių“ (angl. Contactless) technologijų plètrą, užsakymų procesų automatizavimą ir robotizavimą, dèl to gali sparčiau mažèti rutininių ir žemos kvalifikacijos darbų. Didžioji dauguma paslaugų ir veiklų perkeliamos ị skaitmeninę erdvę. Atliepiant šias tendencijas, svarbu, kad darbuotojai mokètų naudotis šiuolaikinèmis skaitmeninėmis technologijomis ir, atitinkamai persikvalifikavę, turètų potencialo augti ateityje.

Globalios pandemijos paveikta turizmo industrija skatina pomėgiais, ịvairiais interesais pagrịstas suasmenintas (angl. taylor-made) paslaugas ar net specifinių, iki pandemijos buvusių populiariausių turizmo paslaugų rekonstrukciją. Autorių nuomone, svarbiausia - teisingai suformuoti kliento lūkesčiai, tad organizacijų internetiniuose puslapiuose siūloma klientams palikti telefono numeri ar elektroninio pašto adresą, kad būtų galima tiesiogiai su juo susisiekti ir užmezgus asmeninị ryši parduoti tai, kas atitinka jo norus. Galima numanyti, kad populiaresnès taps didelès turizmo įmonių aglomeracijos dèl didesnių atšauktų turizmo paslaugų už- 
statų grąžinimo garantijų ir platesnio paslaugų pasirinkimo, be to, tikètina, kad privalomi taps medicininiai draudimai bei elektroniniai skiepų pasai.

Tikètina ir tai, kad dèl inovacinių technologijų plètros mažès verslo kelionių pardavimų. Ši reiškinị, be tiesioginès pandemijos ịtakos, lèmé ir naujų internetinių vaizdo konferencijų platformų, tokių kaip Zoom, Microsoft Teams bei Google Meet, atsiradimas. Rinkoje vis labiau populiarejja kita verslo kelionių rūšis - darbo atostogos (angl. Workation), kada dirbama nuotoliniu būdu iš pasirinktos vietos. Tai unikali galimybė dirbti ir ilgesnị laiką ilsètis vienos kelionès metu. Darbo atostogoms paprastai būna suderinti viešbučiai, siūlomos įvairios trukmès kelionès. Verta atkreipti dèmesi i kitas turizmo verslui reikšmingas valstybes, tokias kaip Sakartvelas, Tunisas ar Egiptas, kurios atitinka visus saugumo reikalavimus, taip pat atokesnes Graikijos ir kitu valstybiu salas, kur sergamumas santykinai mažas. Globalusis turizmas ateityje taps mažiau pelningas transakcijų lygiu dèl pandemijos laikotarpiu prarastų darbo vietų ir pajamų šaltinių, bet bus paprastesnis, skaitmeninis, orientuotas į asmenines patirtis ir išgyvenimus.

\section{Išvados}

COVID-19 pandemijos sukelta krizė neigiamai paveikẻ visų pasaulio šalių ekonomikas. Kuo didesnè viruso sklaida šalyje, tuo griežtesnius veiklos apribojimus taikè valstybės. Turizmas siejamas su tokiomis ekonominio proceso struktūromis, kaip šalies ịvaizdis, valiutinès ịplaukos, paslaugų, aptarnavimo sektorių plètra, naujos darbo vietos, esamos infrastruktūros panaudojimas ir tobulinimas. Turizmas yra viena didžiausių privataus ekonomikos sektoriaus industrijų. Prasidejjus COVID-19 pandemijai, bendrai viso pasaulio valstybių pajamos iš turizmo neteko 1,3 trilijono JAV dolerių, tai sudaro 11 kartų didesnius nuostolius nei pasaulinès ekonominès krizès metu 2009 metais. 120 milijonų darbo vietų, tiesiogiai susijusių su turizmo paslaugomis, patyre išlikimo riziką. Remiantis pateiktais statistiniais duomenimis galima teigti, kad dèl pandemijos kelionių industrija smuko ị prieš trisdešimt metų buvusị lygị ir tiesiogiai paveikẻ kruizų, aviacijos, apgyvendinimo bei kelionių organizavimo verslus. Dèl COVID-19 protrūkio turizmo sektorius patyrẻ precedento neturintị spaudimą ir yra priverstas restruktūrizuoti veiklą. Trys praeito amžiaus krizès jau transformavo šią industriją, nors kelionių industrija yra atspari ir nuolatos atsinaujinanti, žmonių keliavimo ịpročiai keičiasi. Kaitos prielaidos glūdi ankstesnèse praeito amžiaus krizèse. Per pastarajji šimtmetị ịvykęs Antrasis pasaulinis karas lėmè spartų aviacijos technologijų vystymąsi, Rugsėjo 11-oji lèmè saugumo reikalavimų pokyčius, $2008 \mathrm{~m}$. finansų krizė pakeitė keliavimo, atsiskaitymo ir bendravimo ịpročius. Šimtams milijonų žmonių esant karanti- 
ne, uždarius sienas, o skrydžiams sumažèjus 65 proc., tikètina, koronavirusas taps ketvirtaja didžiaja krize šiuolaikinèje turizmo istorijoje.

Fundamentalūs COVID-19 sukelti rinkos pokyčiai, interneto skvarba ir technologijų vystymasis verčia turizmo sektorių restruktūrizuotis. Patiriant daugybę naujų iššūkių, rinkos kaitos veiksnių ịvertinimas gali būti pagrindinis elementas, leisiantis išlikti versle. Pasaulio mastu turizmo industrijai prognozuojamas 3-5 metu atsigavimo laikotarpis. O tol, kol yra apribojimų, viskas priklauso nuo vyriausybiu lankstumo bei noro atrasti vartotojams ir verslui palankių sprendimų, kurie neprieštarautų sveikatos saugumo reikalavimams. Sklandus ir savalaikis ịmonių veiklos restruktūrizavimo procesas leidžia laikinų sunkumų turinčioms įmonėms performuoti savo veiklą keičiant ịmonès strategiją, atsisakant nepelningų veiklos formų ir koncentruojantis ties veiksmingiausiomis. Sėkmingai sunkumus įveikia tos įmonès, kurios preventyviai stebi ir vertina esminius veiklos rodiklius: jei rodikliai netenkina, imasi visų įmanomų veiklos gerinimo priemonių. Atlikus mokslinių straipsnių analizę, išskirtos priemonès, leisiančios sėkmingai igyvendinti turizmo verslo restruktūrizaciją po pandemijos: investicijos ị darbuotojus ir inovacijas, teisingas klientų lūkesčių formulavimas, išlaidų optimizavimas, maksimalus valstybès lešų panaudojimas, lanksčios pardavimų sąlygos, nuolatinis bendradarbiavimas ir sąlygų su paslaugų tiekejjais gerinimas, užstatų iš partnerių grąžinimas, susitelkimas ties būsimais pardavimais, rūpinimasis esamais klientais, pasiūlos plètra ị saugias teritorijas, skaitmeninio skiepų paso įvedimas bei visapusiškas lankstumas.

Turizmo industrijoje veiklą vykdančių įmonių likvidumui palaikyti globaliu mastu teikiamos paskolos su atitinkamos valstybès garantija, taikomos prastovų sistemos smulkioms ir vidutinėms įmonèms, subsidijos, nuomos ir palūkanų kompensavimo priemonès, deramasi su kreditoriais ir partneriais, iš dalies perorientuojama įmonių veikla. Bankrutuojančias organizacijas keičia besikuriančios arba kitų užsienio šalių kapitalo pagrindu steigiamos veržlios, naujus iššūkius gebančios priimti bendrovès. Tačiau besiplečianti turizmo industrija negali niveliuoti asmeninių keliautojų patirčių, čia būtina subtili darna. Taigi moduliuojant kelionių organizavimo ateiti galima pasitelkti dvi skirtingas prognozes - artimają ir tolimają: manytina, kad artimiausioje ateityje keliaujama bus rečiau ir ị artimesnes teritorijas, bus siekiama darnos, kelionès, be abejo, bus brangesnès dèl papildomo testavimo, tačiau ilgalaikèje perspektyvoje tikètina, jog kelerių metų pauzè, kai turistai prisikeliaus savose ir aplinkinèse valstybėse, atsiradus globaliems elektroniniams skiepų pasams, turizmo intensyvumas, patirčių, egzotinių šalių ir pramogų poreikis išaugs ir pasieks priešpandeminị laikotarpị. 


\section{COVID-19 PANDEMIJOS IৃTAKA PASAULIO EKONOMIKAI TURIZMO INDUSTRIJOS...}

\section{Literatūra}

[AHLA] American Hotel and Logging Assiciation. (2020). Survey of hotels on financial crisis. Prieiga internete: https://www.ahla.com/covid-19s-impact-hotel-industry [žiūrèta 2021-03-09].

Bakar, N. A., Rosbi, S. (2020). Effect of Coronavirus (COVID-19) disease on tourism industry. International Journal of advanced ingeneering research and science (IJAERS), Vol. 7, Issue 4, Apr-2020 ISSN: 23496495(P) | 2456-1908(O).

Baldwin, R., Di Mauro, B. W. (2020). Economics in the time of Covid-19. Centre for Economic Policy Research. London. ISBN: 978-1-912179-28-2.

Barua, S. (2020). Understanding Coronanomics: The economic implications of the coronavirus (COVID-19) pandemic [Manuscript].

Baum, T., Hai, N. T. T. (2020). Hospitality, tourism, human rights and the impact of COVID19. International Journal of Contemporary Hospitality Management, Vol. 32(7), p. 2397-2407.

Benbouziane, M., Saidi, T. (2020). The universal impact of the health crises on the international tourism: the COVID-19 pandemic as a case. Business Excellence and Management, Faculty of Management, Academy of Economic Studies, Vol. 10(5), p. 98-111. Bucharest, Romania.

Business Insider. (2021). A British man is offering ghost ship tours of abandoned cruise ships in the English Channel. Prieiga internete: https:/www.businessinsider.in/thelife/news/a-british-man-is-offering-ghost-shiptours-of-abandoned-cruise-ships-in-the-english-channel/articleshow/77731796.cms [žiūrèta 2021-03-06].

Centeno, R. S., Marquez, J. P. (2020). How much did the Tourism Industry Lost? Estimating Earning Loss of Tourism in the Philippines. Cornell University.

Chris, B., Hirt, M., Hudson, S., Northcote N., Smit, S. (2020). The great acceleration. McKinsey \& Company. Prieiga internete: https://www.mckinsey.com/business-functions/strategy-and-corporate-finance/ourinsights/the-great-acceleration?cid=other-eml-altmipmck\&hlkid=33f92356dad34cd3a14c8e964310e224\&h $\underline{\mathrm{ctky}}=1543015 \& \mathrm{chdpid}=\mathrm{d} 9 \mathrm{cf6b} 8 \mathrm{a}-1 \mathrm{~d} 54-4 \mathrm{~d} 03-8 \mathrm{~b} 7 \mathrm{~b}-\mathrm{be} 32198560 \mathrm{be}$ [Žiūrèta 2021-03-15].

Correa-Martínez, C. L., Kampmeier, S., Kümpers, P., Schwierzeck, V., Hennies, M., Hafezi, W. (...), Mellmann, A. (2020). A pandemic in times of global tourism: superspreading and exportation of COVID-19 cases from a ski area in Austria. American Society of Microbiology. Journal of clinical microbiology. Doi: 10.1128/ JCM.00588-20.

Costaguta, A. (2020). The coronavirus outbreak: the unprecedented shock to aviation. News and features by ICAO.

Čiužas, A. (2021). Dokumentų analizè. Visuotine lietuviu enciklopedija. Prieiga internete: https://www.vle.lt/ straipsnis/dokumentu-analize [žiūrèta 2021-03-19].

Dinarto, D., Wanto, A., Sebastian, L. C. (2020). Global health security-COVID-19: impact on Bintan's tourism sector. RSIS Commentaries, Singapore.

Eurocontol. (2021). Comprehensive assesment of Covid-19's impact on European air traffic. Supporting European Aviation. Prieiga internete: https://www.eurocontrol.int/publication/eurocontrol-comprehensive-assessmentcovid-19s-impact-european-air-traffic [žiūrèta 2021-03-10].

[EP] Europos Parlamentas. (2021). Turizmas. Faktu apie Europos Sajunga suvestinès. Prieiga internete: https:// www.europarl.europa.eu/factsheets/lt/indexsearch?query=turizmas [žiūrèta 2021-05-05].

[ESKK] Europos Sajungos Komisijos Komunikatas. (2020). 4-asis laikinosios valstybès pagalbos priemoniu, skirtu ekonomikai remti reaguojant $i$ dabartini COVID-19 protrūki, sistemos pakeitimas ir Komisijos komunikato valstybèms narèms dèl Sutarties dèl Europos Sajungos veikimo 107 ir 108 straipsniu taikymo trumpalaikiam eksporto kredito draudimui priedo pakeitimas. Dokumentas C340I. Prieiga internete: https://eur-lex.europa.eu/legalcontent/LT/TXT/HTML/?uri=OJ:C:2020:340I:FULL\&from=EN [žiūrèta 2021-03-01].

Fernandes, N. (2020). Economic effects of coronavirus outbreak (COVID-19) on the world economy. Spain: IESE Business school.

Gonzales-Torres, Th., Rodriguez-Sanches, J. L., Pelechano-Barahona, E. (2021). Managing relationships in the tourism supply chain to overcome epidemic outbreaks: The case of Covid-19 and the hospitality industry in Spain. International Journal of Hospitality Management, Vol. 92, p. 2, Spain.

Gössling, S., Scott, D., Hall, C. M. (2020). Pandemics, tourism and global change: a rapid assessment of COVID-19. Journal of Sustainable Tourism, Vol. 29 (1), p. 5. 


\section{Rima Karsokienè, Leta Dromantienè}

Haywood, K. M. (2020). A post COVID-19 future - tourism re-imagined and re-enabled. Tourism geographies Journal, Vol. 22, No. 3, p. 599-609. Canada: College of Management and Economics, University of Guelph, Guelph.

Jucaitytė, I., Maščinskienė, J. (2012). Turizmo vietovių po krizinių ịvykių patrauklumo valdymas. Economics and Management, Vol. 17(3), p. 1077. ISSN 2029-9338.

Kantar. (2020). More than half of global business leaders don't expect economic recovery until 2022. Prieiga internete: https://www.kantar.com/inspiration/coronavirus/more-than-half-of-global-business-leaders-dontexpect-economic-recovery-until-2022 [žiūrèta 2021-03-20].

Klonowska, K., Bindt, P. (2020). The COVID-19 pandemic: two waves of technological responses in the European Union. Hague Centre for Strategic Studies.

Law, R., Leung, R., Buhalis, D. (2009). Information Technology Applications in Hospitality and Tourism: a Review of Publications from 2005 to 2007. Prieiga internete: https://doi.org/10.1080/10548400903163160 [žiūrèta 2021-03-12].

Maditinos, Z., Vassiliadis, Ch. (2008). Crises and Disasters in Tourism Industry: Happen locally-Affect globally. Mibes e-book. Greece: Dpt of Business Administration, University of Macedonia, Thessaloniki, $71 \mathrm{p}$.

Mayers, J. F., Snyder, R. E., Porshe, C. C. et al (2020). Identification and monitoring of international travellers during the initial phase of an outbreak of Covid-19. Morbidity and Mortality Weekly Report, Vol. 69, p. 599. US: Department of Health and Human services.

Menegaki, A. N. (2020). Hedging feasibility perspectives against the COVID-19 in the international tourism sector. Preprints, social sciences, economics 2020040536. Doi: 10.20944/preprints202004.0536.vl [žiūrèta 2021-03-09].

Nepal, S. K. (2020). Adventure travel and tourism after COVID-19 - business as usual or opportunity to reset? Tourism Geographies - An International Journal of Tourism Space. Place and Environment. ISSN: 14616688 (Print) 1470-1340 (Online).

Statista. (2021). Tourism worldwide statistics. Prieiga internete: https://www.statista.com/search/?q=tourism\&Se arch=\&qKat=search [žiūrèta 2021-03-09].

Strictland, J. L. (2020). Airlines in crisis of covid 19. Webinar. Prieiga internete: www.jlsconsultancy.co.uk [žiūrèta 2020-05-15].

Thams, A., Zech, N., Rempel, D., Ayia-Koi, A. (2020). An initial assessment of economic impacts and operational challenges for the tourism \& hospitality industry due to COVID-19. IUBH Discussion Papers - Tourismus \& Hospitality, No. 2, p. 9. Provided in Cooperation with: IUBH University of Applied Sciences, Erfurt, Germany.

Ugur, N. G., Akbiyik, A. (2020). Impacts of COVID-19 on global tourism industry: A crossregional comparison. Tourism Management Perspectives Journal. PII: S2211-9736(20)30111-2.

[UNWTO] United Nations World Tourism Organization. (2019). International Tourism Highlights. Dreamstime. com, Madrid, Spain. ISBN printed version: 978-92-844-2114-5 ISBN electronic version: 978-92-844-2115-2. Doi: 10.18111/9789284421152 [žiūrèta 2020-06-03].

[UNWTO] United Nations World Tourism Organisation. (2020). International Tourism down 70\% as travel restrictions impact all regions. Prieiga internete: https://www.unwto.org/news/international-tourism-down70-as-travel-restrictions-impact-all-regions [žiūrèta 2021-03-02].

[UNWTO] United Nations World Tourism Organisation. (2021). 2020: worst year in tourism history with 1 billion fewer international arrivals. Prieiga internete:

https://www.unwto.org/news/2020-worst-year-in-tourism-history-with-1-billion-fewer-international-arrivals [žiūrèta 2021-03-02]. 


\section{THE IMPACT OF THE COVID-19 PANDEMIC ON THE WORLD ECONOMY THROUGH THE PRISM OF THE TOURISM INDUSTRY}

\section{Rima Karsokienė, Leta Dromantienė}

Summary

The relevance of this paper is that the Covid-19 pandemic that was announced by the WHO on 30 March 2020 has caused blockages in all economic sectors, but tourism is the most affected. It is difficult to estimate the real impact of the pandemic on international tourism. According to the UNWTO, prior to the pandemic, the tourism sector generated $10 \%$ of global GDP, and accounted for one out of ten jobs worldwide. Quarantine measures, flight cancellations, bans and border closures are expected to significantly reduce tourism for several years. Every country in the world has been affected by the pandemic. This article presents the effects of the Covid-19 pandemic on the tourism sector globally, which includes the cruise ship and airline industries, and also accommodation.

Globalisation and the international movement of people facilitated the crossborder spread of the Covid-19 virus. Human travel has contributed to this public health crisis. Travel restrictions imposed to stop the spread of the virus have had a devastating effect on the entire tourism industry worldwide. The onset of the pandemic in the European Union (EU) alone has put 13 million jobs at risk. EU support for its members to revitalise the tourism sector following the coronavirus pandemic is estimated at 255 billion euros. Another 120 billion euros will provide additional investment, which should help tourism entrepreneurs to recover.

According to the European Parliament, the tourism industry in the European Union alone (traditional holiday and tourism service providers) accounts for 2.3 million jobs. Enterprises, mainly small and medium-size enterprises, employ around 12.3 million people. In 2014, one in ten European non-financial economies belonged to the tourism sector. In 2018, the EU travel and tourism sector generated directly $3.9 \%$ of GDP, and $5.1 \%$ of jobs, which means it employed about 11.9 million people. Assessing the close ties between the tourism sector and other sectors of the economy, it is estimated that its contribution is even higher, at $10.3 \%$ of GDP, and $11.7 \%$ of all jobs, meaning that 27.3 million people were employed in it (2021).

Numerous analyses of the tourism sector have been carried out at various levels, both regionally and globally. D. Dinarto, A. Wanto and L. C. Sebastian (2020) investigated the impact of Covid-19 on the accommodation sector on Bintan Island, Riau Archipelago, Indonesia. R. S. Centeno and J. P. Marques (2020) examined 
losses in the tourism sector in the Philippines. In Europe, L. C. Correa-Martines et al. (2020) analysed the impact of the Covid-19 pandemic on Austrian ski resorts. S. K. Nepal (2020) analysed the effects of the pandemic on Nepal's tourism sector in a scientific article. There are also a number of scientific works examining the impact of the virus on the tourism industry on a global level. S. Gossling, D. Scott and C. M. Hall (2020) assessed the effects of international quarantine restrictions on the tourism industry, and also analysed the impact of quarantine on human psychology. N. G. Ugur and A. Akbiyik (2020) performed an analysis of data in the Trip Advisor portal, which revealed the reasons for travellers' fears and the mass cancellation of their reservations.

The Covid-19 pandemic has impacted the global tourism and hospitality sector not only economically but also socially. Tourism is a fast-changing industry, which depends on many external and internal factors. These are economic, political and social factors, although the highly competitive market and rapid changes during the pandemic have obliged companies to look for new ways and better solutions to create value for their customers and to stay competitive in the market. The aim of this work is to look at the impact of Covid-19 on global economies, particularly the tourism sector worldwide, and the possibilities for its further successful development.

The research methodology consists of an analysis of scientific literature, and documentary and statistical data, regarding the effects of the coronavirus pandemic on the tourism sector.

The results underline that the Covid-19 pandemic has affected the tourism sector significantly. Companies are forced to restructure their businesses and to adopt new business models in order to continue to be successful in the long term, which, on the other hand, enables them to adapt more flexibly by gaining more visibility; to maximise asset utilisation and yield in airlines, hotels and cruise ships; to ensure customers have safe and enjoyable holidays.

Conclusions. The demands of the present pandemic situation work like an interrogation, a re-exploration and a re-envisioning of the future of the tourism industry. The segregation is between what has to change and what has to remain constant. Despite the crippling effects of Covid-19, new forms of adaptation are emerging that challenge the prevailing business competitiveness ethic. While a transactional economic revival of companies has to remain the top priority, progress will advance as long as tourism becomes more transformational.

Fundamental changes to the market, internet penetration and technological developments caused by Covid-19 are forcing the tourism sector to reorganise. In the face of many new challenges, assessing the drivers of market change can be a key element in successfully staying in business. Globally, the tourism industry is 
projected to recover in three to five years. And as long as restrictions exist, it all depends on the flexibility of governments and the desire to find consumer and business-friendly solutions that do not conflict with health and safety requirements. The smooth and timely process of corporate reorganisation allows companies in temporary difficulty to reshape their operations by changing the company's strategy, abandoning unprofitable forms of activity, and focusing on the most efficient ones. The difficulties are overcome successfully by companies that proactively monitor and evaluate key performance indicators: if the indicators are not satisfactory, they take all possible measures to improve performance. The measures identified in the analysis of scientific articles to implement the successful reorganisation of the tourism business after the pandemic are as follows: investment in employees and innovation, correctly formed customer expectations, cost-effectiveness, the maximum use of public funds, flexible sales conditions, continuous cooperation and improvement with service providers, the return of deposits from partners, a focus on future sales, caring for existing customers, expanding supply to safe areas, introducing a digital vaccine passport, and comprehensive flexibility.

Leta Dromantienè - profesorè, daktare (humanitariniai mokslai - istorija), HP (socialiniai mokslai - vadyba) Klaipédos universiteto Sporto, rekreacijos ir turizmo katedra.

El. paštas: 1eta.dromantienė@ku.1t 